\title{
ANALISIS NILAI-NILAI PENDIDIKAN KARAKTER DALAM NOVEL DAUN YANG JATUH TAK PERNAH MEMBENCI ANGIN KARYA TERE LIYE
}

\author{
Nurmawati \\ nurmamansyur46@yahoo.com \\ Madrasah Tsanawiyah Pondok Pesantren Pancasila Bengkulu
}

\begin{abstract}
Abstrak
The purpose of this study to get an explanation on the description of the Analysis of character education Daun yang Jatuh Tak Pernah Membenci Angin Novel By Tere Liye. This research uses descriptive analysis method. descriptive analysis method used in this study means to obtain an accurate picture of the values of character education in novel Daun yang Jatuh Tak Pernah Membenci Angin Novel By Tere Liye. Technique Data collection was done by using the documentation that specifically examined the values of character education in novel Daun yang Jatuh Tak Pernah Membenci Angin Novel By Tere Liye. Based on the analysis of educational values contained in this novel there are as follows (1) relegius educational value such as prayer, grave pilgrimage, grateful (2) hard work as diligently and passionately in the work, (3) such as smart creative thinking and create the new things, (4) appreciate achievements such as awards to and achievement, (5) independent as not to depend on others, (6) curiosity such as asking questions, (7) friends / communicative as happy hanging out with other people, (8) social care such as giving comfort to those in need, and (9) responsibilities such as completing tasks without being asked or told.
\end{abstract}

Kata Kunci: Values , Character Education, Daun Yang Jatuh Tak Pernah Membenci Angin, Tere Liye

\section{PENDAHULUAN}

Pendidikan karakter menjadi pembahasan penting pemerintah dalam dunia pendidikan di Indonesia. Dilihat dari fenomena yang ada nilai pendidikan karakter siswa memprihatinkan seperti yang terdapat pada berita-berita media cetak atau media elektronik, yang memberitakan perilaku pelajar mengarah pada krisis karakter. Sehingga pengembangan nilai pendidikan karakter perlu ditanamkan pada peserta didik salah satunya melalui pengajaran sastra. Oleh karena itu, perlu dilakukakan penelitian tentang pendidikan karakter dalam sastra untuk menambah wawasan nilai pendidikan karakter. Berdasarkan penelitian terdahulu telah memberikan kontribusi bagi perkembangkan nilai pendidikan karakter. Sejalan dengan itu penelitian ini juga memperkaya kajian nilai pendidikan karakter untuk menambah pengetahuan dalam pembentukan karakter siswa melalui pengajaran sastra.

Pengajaran sastra memiliki peran bagi pemupukan kecerdasan siswa dalam semua aspek termasuk karakter. Artinya sastra menjadi sangat penting, tidak hanya sastra berperan dalam penanaman fondasi keluhuran budi pekerti, melaikan sastra juga memiliki andil dalam pembentukan karakter yang jujur sejak dini. Melalui pergulatan dan pertemuan intensif dengan teks-teks sastra para siswa akan mendapatkan 
bekal pengetahuan yang mendalam tentang manusia, hidup dan kehidupan, serta berbagai kompleksitas problematika dimensi hidup yang disebabkan oleh arus modernisasi.

Sejatinya pengajaran sastra mampu dijadikan pintu masuk dalam penanaman nilai-nilai pendidikan karakter/moral seperti kejujuran, pengorbanan, demokrasi, santun, dan sebagainya banyak ditemukan dalam karya-karya sastra. Baik puisi, cerpen, novel maupun drama. Apabila karya sastra itu dibaca dipahami isi dan maknanya serta ditanamkan pada diri siswa. Maka siswa akan menjujung nilainilai pendidikan karakter.

Pentingnya pemilihan nilai pendidikan karakter dalam penelitian ini karena, menurut peneliti sejalan dengan keadaan sekarang, karena banyak fenomena-fenomena yang terjadi di tengah masyarakat yang terkadang tidak mengindahkan tentang prilaku-prilaku menyimpang. Pengaruh arus modernisasi telah banyak member perubahan dalam kehidupan masyarakat. Namun, yang menyedihkan adalah perubahan yang terjadi justru cendrung mengarah pada krisis karakter, moral dan akhlak. Arus modernisasi telah banyak memberi perubahan dalam kehidupan masyarakat, yang menyedihkan perubahan yang terjadi justru cendrung mengarah pada krisis moral dan akhlak. Krisis moral dapat diatasi dengan pembinaan karakter dalam lingkungan sekolah melalui pengajaran sastra yang berdimensi karakter/moral.

Salah satu karya sastra yang mengandung nilai pendidikan karakter adalah novel. Novel menjadi bagian dari pengalaman manusia, baik dari aspek manusia yang memanfaatkannya bagi pengalaman hidupnya, maupun dari aspek penciptaannya mengekspresikan pengalaman batinnya ke dalam karya sastra. Novel merupakan pengalaman batin penciptanya mengenai kehidupan masyarakat. Di dalam karya sastra dilukiskan keadaan dan kehidupan sosial suatu masyarakat, peristiwa-peristiwa, serta nilai-nilai yang diamanatkan pencipta lewat tokoh-tokoh cerita. Sastra mempersoalkan kehidupan manusia dalam berbagai kehidupannya.

Alasan peneliti memilih novel ini karena, merupakan hasil karya dari novelis terbaik Indonesia. Novel ini juga sangat laris di pasaran dan diminati oleh masyarakat pembaca sastra. Terbukti novel ini sudah dicetak ulang sebanyak 22 kali dalam kurun waktu 2 tahun. Novel ini menceritakan perjuangan hidup seorang perempuan yang menafkahi keluargannya karena ayahnya sudah tidak ada, bahkan ia harus mengurus ibunya yang menderita kanker stadium IV. Tetapi dia tetap gigih dalam menghadapi halangan dan rintangan. Selain itu, nbevel adalah hasil karya dari salah satu novelis terbesar di Indonesia yaitu Tere Liye. Sebagai penulis novel best seller. Tere Liye dijadikan nama pena dari nama "Darwis" Tere Liye. Tere Liye dalam bahasa India berarti untukmu. Sebagai seorang penulis, beliau terhubung dengan penggemarnya di fans page Facebook dengan nama Darwis Tere Liye. Beberapa karya Tere Liye antara lain, Pukat, Burlian, Hafalan Shalat Delisa, Moga Bunda Disayang Allah, Bidadari - Bidadari Surga, Sang Penandai, Rembulan Tenggelam di Wajahmu, Mimpi-Mimpi Si Patah Hati, Cintaku Antara Jakarta dan Kuala Lumpur, Senja Bersama Rosie, Eliana, Serial Anak-Anak Mamak. 
Sepengetahuan peneliti novel Daun Yang Jatuh Tak Pernah Membenci Angin karya Tere Liye belum pernah dikaji oleh peneliti lain, berdasarkan penelusuran penulis di internet.

\section{METODE PENELITIAN}

Metode yang digunakan dalam penelitian ini adalah metode deskriptif analisis. Menurut Ratna (2012: 53) metode deskriptif analisis dilakukan dengan cara mendeskripsikan fakta-fakta yang kemudian disusul dengan analisis. Metode deskriptif dalam penelitian ini dimaksud untuk mendeskripsikan secara akurat mengenai fakta-fakta dan hubungannya dengan fenomena yang telah diselidiki. Metode ini tidak hanya terbatas pada pengumpulan data dan penyusunan data, tetapi juga meliputi analisis dan interpretasi itu sendiri.

Jadi metode deskriptif analisis dalam penelitian ini digunakan sebagai sarana untuk memperoleh suatu gambaran yang cermat mengenai nilainilai pendidikan karakter dalam novel Daun yang Jatuh Tak Pernah Membenci Angin karya Tere Liye

\section{Teknik Pengumpulan Data}

Teknik pengumpulan data dalam penelitian ini adalah teknik dokumentasi. Menurut Sugiyono (2014: 326) dokumentasi merupakan cara mengumpulkan data melalui peninggalan tertulis, seperti arsip-arsip dan termasuk juga novel, buku-buku tentang pendapat, teori, dalil atau hukum-hukum dan lainlain yang berhubungan dengan masalah penelitian. Teknik dokumentasi yang secara khusus meneliti nilai-nilai pendidikan karakter dalam novel Daun yang Jatuh Tak Pernah Membenci Angin karya Tere Liye.
Teknik Analisis data

Analisis data yang digunakan dalam penelitian ini menggunakan langkah-langkah analisis data yang digunakan sebagai berikut: (1) membaca novel Daun yang Jatuh Tak Pernah Membenci Angin karya Tere Liye untuk mengetahui makna secara keseluruhannya, (2) membaca ulang novel Daun yang Jatuh Tak Pernah Membenci Angin karya Tere Liye, disertai dengan pemberian garis bawah dengan tinta berwarna yang berhubungan dengan masalah penelitian yaitu nilainilai pendidikan karakter, mengumpulkan seluruh nilai-nilai pendidikan karakter yang sudah ditandai pada teks novel Daun yang Jatuh Tak Pernah Membenci Angin karya Tere Liye, ke dalam daftar pengumpulan data, (4) mengidentifikasi berdasarkan bentuk nilai-nilai pendidikan karakter yang telah disampaikan di atas, (5) mengklasifikasi bentuk nilai-nilai pendidikan karakter, (6) menganalisis nilai-nilai pendidikan karakter untuk dideskripsikan nilai-nilai pendidikan karakter dalam novel Daun yang Jatuh Tak Pernah Membenci Angin karya Tere Liye, (7) menyimpulkan hasil penelitian.

\section{HASIL DAN PEMBAHASAN}

Hasil Penelitian

1. Nilai-nilai Pendidikan Karakter dalam Novel Daun Yang Jatuh Tak Pernah Membenci Angin Karya Tere Liye Penelitian tentang pendidikan karakter dalam karya satra yaitu novel bukan hal yang baru. Karena sudah pernah diteliti oleh Maria Hendrika dengan judul "Pendidikan Karakter dalam Novel Ayah Mengapa Aku Berbeda Karya Agnes 
Devonar. Pada penelitian tersebut nilai pendidikan karakter yang ditemukan meliputi religious, jujur, toleransi, disiplin, kerja keras, kreatif, mandiri, rasa ingin tahu, menghargai prestasi, bersahabat/komunikatif, cinta damai peduli sosial, dan tanggung jawab.

Novel yang diteliti oleh Maria Hendrika, menceritakan tentang seorang gadis yang kekurangan atau mengalami cacat bawaan. Artinya nilai pendidikan karakter yang ditemukan Maria dalam novel tersebut berasal dari tokoh yang tidak normal. Oleh karena itulah perlu dilakukan penelitian lanjutan pada tokoh yang normal pada novel Daun Yang Jatuh Tak Pernah Mambenci Angin karya Tere Liye. Novel ini menceritakan perjuangan hidup kakak beradik untuk mencukupi kebutuhan sehari-hari dan biaya berobat ibunya dengan mengamen dari bus ke bus. Nilainilai pendidikan karakter dalam novel Daun Yang Jatuh Tak Pernah Mambenci Angin karya Tere Liye akan dianalisis berdasarkan perilaku-perilaku yang digambarkan oleh tokoh, dialog-dialog para tokoh dan narasi atau cerita yang merupakan alur peristiwa yang dikemukakan oleh pengarang.

Berdasarkan hasil penelitian yang telah peneliti lakukan, nilai pendidikan karakter yang terdapat dalam novel Daun Yang Jatuh Tak Pernah Mambenci Angin karya Tere Liye adalah (1) religius, (2) kerja keras, (3) kreatif, (4) menghargai prestasi, (5) mandiri, (6) rasa ingin tahu, (7) bersahabat/komunikatif, (8) peduli sosial, dan (9) tanggung jawab.

1. Religius

a. Suka berdoa Sebelum dan Sesudah Melakukan Sesuatu

Suka berdoa sebelum dan sesudah aktifitas merupakan salah satu bentuk sikap dan perilaku religius. Karena dalam ajaran agama di balik sikap berserah diri manusia wajib berdoa dan berusaha saat memiliki tujuan atau rencana yang tengah ditargetkan. Hal tersebut tergambar pada kutipan berikut:

"Ya Tuhan, aku tak bisa membayangkan apa yang akan terjaddi jika lbu tidak kunjung sembuh. Dalam doa-doa aku hanya menyebut kesembuhan lbu. Aku tak ingin kehilanganya. Lihatlah apa yang akan terjadi kalau dia pergi. Aku sering menangis sambil memeluk tubuh Ibu yang semakin mengecil" (Liye, 2016:54).

Konteks

Tokoh Tania selalu medoakan ibunya agar secepatnya sembuh, dia tidak ingin kehilangan ibunya. Tania tidak sanggup ditinggal oleh ibunya.

Dari kutipan tersebut terlihat adanya nilai pendidikan relegius yaitu tokoh Dede yang mendo'akan ibunya yang sudah meninggal semoga Ibunya bahagia di surga. Hal itu menggambarkan tokoh Dede memiliki karakter religius pada aspek selalu mendoakan kedua orang tua. Sikap tersebut merupakan salah satu sikap relegius dalam bentuk berbakti kepada kedua orang tua.

b. Patuh dalam Menjalankan Ajaran Agama dan Berserah Diri Kepada Tuhan Berdasarkan hasil penelitian karakter patuh dalam menjalankan ajaran agama dan berserah diri kepada tuhan dalam novel Daun yang Jatuh Tak Pernah Membenci Angin karya Tere Liye berupa bersyukur, berbakti kepada orang tua, iklhas tanpa pamrih dan dan berziarah kubur. Berikut salah satu kutipan yang menunjukan adanya nilai relegius taat dalam menjalankan ajaran agama terlihat pada kutipan di bawah ini:

"Aku, adikku dan Adi (yang pagi-pagi sudah datang ke rumah) pergi kepusara ibu. Dede membawa empat tangkai bunga mawar 
merah. Ini kebiasaaannya. Adikku setiap minggu selama delapan tahun terakhir selalu dating ke pemakaman ibu. Membawa mawar merah, mengadu, bercerita" (Tere Liye, 2016:193).

Konteks

Tania, Dede dan Adi pergi berziarah ke pusara Ibu. Dede membawa empat tangkai bunga mawar merah, dan hal tersebut merupkan kebiasan Dede. Selama delapan tahun terakhir Dede setiap malam minggu selalu ke pusara Ibu, membawa mawar merah, bercerita dan mengadu pada sang lbu.

Berdasarkan kutipan tersebut dapat dilihat adanya nilai relegius yang digambarkan pengarang pada tokoh Tania, Dede dan Adi. Nilai pendidikan religius dari ketiga tokoh tersebut yaitu mereka pergi ke pusara lbu mereka, karena agama mengajarkan untuk berziarah kubur terhadap yang telah meninggal.

\section{Kerja Keras}

Kerja keras yaitu perilaku yang menunjukan upaya sungguh-sungguh dalam mengatasi berbagai hambatan belajar dan tugas, serta menyelesaikan tugas dengan sebaik-baiknya. Berdasarkan hasil penelitian nilai pendidikan kerja keras dalam novel Daun yang Jatuh Tak Pernah Membenci Angin karya Tere Liye ditemukan sebanyak 17 kutipan. Berdasarkan hasil penelitian penggambaran nilai pendidikan karakter kerja keras sebagai berikut.

a. Rajin dalam Melakukan Pekerjaan

Rajin dalam melakukan pekerjaan merupakan salah satu bentuk indikator dari kerja keras. Orang yang selalu bekerja keras, akan menjadi orang yang sukses. Karena kesuksesan itu didapat dengan usaha dan selalu bekerja keras.
Berikut ini salah satu contoh sikap bekerja keras dalam novel Daun Yang Jatuh Membenci Angin Tere Liye.

Malam sudah larut. Hamper jam delapan. Aku memutuskan untuk pulang, meskipun dengan uang seadanya. Ibu tidak pernah mengomel berapapun uang kami bawa pulang. Jadi kami naik bus jurusan itu (Liye, 2016: 22).

Konteks

Tokoh Tania mengamen sampai dengan jam delapan malam dan mumutuskan untuk pulang dengan pendapatan seadanya.

b. Tekun Dalam Melaksanakan Pekerjaan

Berdasarkan hasil analisis data sikap bekerja keras dengan indikator tekun, teliti dan cermat dalam melaksanakan pekerjaan tergambar pada kutipan dibawah ini.

"Dia yatim piatu sejak bayi (siapa orang tuanya pun tak ada yang tahu). Berjuang di jalanan untuk meneruskan hidup. Sama seperti kami dulu, mungkin lebih menyakitkan karena tidak ada yang berbaik hati membantunya. Setapak demi setapak menancapkan jejak kehidupan" (Tere Liye, 2016:148).

Konteks

Tokoh Danar merupakan inspirasi bagi Tania, karena dengan latar belakang kehidupan yang tidak jauh beda, Danar bisa menjadi orang berhasil dalam karirnya.

c. Enerjik dan Penuh Semangat dalam Bekerja

Berdasarkan analisis data sikap enerjik dan penuh semangat dalam bekerja dalam novel Daun yang Jatuh Tak Pernah Membenci Angin karya Tere Liye digambarkan pengarang pada tokoh Tania yang selalu bersemangat dan tidak pernah mengeluh untuk berjuang demi meneruskan hidupnya.setiap hari selepas pulang sekolah Tania harus pergi 
mengamen, belajar dan membantu ibunya. Tania tidak pernah mengeluh untuk melakukannya. Hal itu tergambar pada kutipan berikut.

"Jam dua belas teng, aku buru-buru pulang ke rumah kardus di bantaran kali. Melempar tas dan buku sembarangan. Makan siang secepat mungkin. Langsung mengganti kostum dan mengambil kencrengan tutup botol. Kami mengamen hingga sore hari. Mengambil rute jarak dekat" (Tere Liye, 2016:33).

Konteks

Tokoh Tania yang baru pulang sekolah buru-buru ganti baju, makan siang dan lansung berangkat mengamen hingga sore.

3. Kreatif

Kreatif yaitu berpikir dan melakukan sesuatu untuk menghasilkan cara atau hasil baru dari sesuatu yang telah dimiliki. Dari hasil penelitian nilai pendidikan karakter kreatif dalam novel Daun yang Jatuh Tak Pernah Membenci Angin karya Tere Liye ditemukan sebanyak 13 kutipan.

a. Memiliki Kemampuan Berpikir Cerdas

Dan Cerdik

Nilai pendidikan kreatif dalam bentuk memiliki kemampuan berpikir cerdas dan cerdik yang ditunjukan pengarang melalui tokoh Tania. Tokoh Tania yang hidup serba kekurangan harus berpikir keras untuk kelanjutan sekolahnya agar tidak hanya lulusan SD. Sehingga dia mencari peluang beasiswa dan didapatnya dua bulan sebelum ibunya meninggal. Beasiswa untuk melanjutkan SMP di Singapura. Bentuk karakter kreatif Tania tergambar pada kutipan berikut.

"Sebenarnya dua bulan sebelum Ibu meninggal, aku mengurus berkas beasiswa ASEAN Scholarship. Beasiswa yang memberikan kesempatan untuk melanjutkan pendidikan junior high school atau SMP di singapura" (Tere Liye, 2016:66).

Konteks

Tokoh Tania mengikuti program beasiswa ASEAN Scholarship dua bulan sebelum ibunya meninggal.

b. Bernalar Tentang Sesuatu Dari Berbagai Perspektif, Melihat Dari Berbagai Arah

Berdasarkan analisis data sikap bernalar tentang sesuatu dari berbagai perspektif, melihat dari berbagai arah dalam novel Daun yang Jatuh Tak Pernah Membenci Angin karya Tere Liye menggambarkan pada tokoh Danar yang mempunyai imajinasi, setelah mendengar kata besar dan cantik tokoh Danar berpikir dan berkhayal banyak hal. Imajinasi merupakan salah satu bentuk dari kreatifitas seseorang. Oleh karena itu, tokoh Danar dapat dikatakan memiliki kreatifitas. Tokoh Danar digambarkan pengarang memiliki pemikiran yang kreatif. Danar menciptakan hal-hal baru seperti di rumahnya Danar setiap hari minggu, dia mengajarkan atau membuka kelas mendongeng untuk anak-anak sekitar rumah kontrakannya. Selain mendongeng Danar juga seorang penulis buku dan juga novel-novel dewasa, hasil tulisannya itulah yang diceritakan lagi pada anak-anak kelas mendongengnya. Sehingga dia tidak perlu lagi membeli buku cerita. Nilai pendidikan karakter kreatif tersebut tergambar pada kutipan berikut.

"Bukan besar dan bagusnya rumah itu yang membuat aku dan adikku betah, melainkan karena setiap hari Minggu dia membuka kelas mendongeng di rumahnya, di ruangan depan yang dipenuhi jejeran lemari. Lemari itu penuh buku. Setiap Minggu pukul 08.00 ruangan itu selalu ramai oleh anak-anak. Anak-anak sekitar rumah kontrakanya. 
Separuhnya kukenali sebagai teman sekolahku sendiri" (Liye, 2016:37).

Konteks

Tokoh Danar membuka kelas mendongeng dirumah kontrakannya untuk anak-anak disekitar kontrakaknnya dengan gratis.

4. Menghargai Prestasi

Sikap dan tindakan yang mendorong dirinya untuk menghasilkan sesutau yang berguna bagi masyarakat dan mengakui serta menghormati keberhasilan orang lain. Nilai pendidikan karakter menghargai prestasi yang diteemukan dalam novel Daun yang Jatuh Tak Pernah Membenci Angin karya Tere Liye ditemukan sebanyak 15 kutipan. Karakter menghargai prestasi tergambar pada tokoh Tania. Semangat belajar Tania yang luar biasa, membuatnya mendapatkan banyak prestasi akademiknya. Dengan berbagai prestasi tersebut timbullah rasa apresiasi dari orang sekitar Tania. Seperti Danar, Ibu, dan sekolahnya yang menghargai prestasi Tania dengan berbagai macam reward. Tokoh Danar menghargai prestasi Tania dalam bentuk pujian karena mendapatkan nilai bagus pada ulangan matematika. bukan hanya pujian yang diberikan Danar sebagai bentuk menghargai prestasi Tania. Danar juga memasukannya untuk kursus bahasa Inggris. hal itu tergambar pada kutipan berikut.

"Kak Tania,bawa legonya, kan? Dede menarik bajuku. Sekarang adikku kelas enam, lebih empat setahun, sama seperti ku dulu, guru-guru di SD menaikanya lompat dua tingkat" (Tere Liye, 2016:79).

Konteks

Ketika Tania pulang dari Singapura, Dede langsung meminta lego yang telah dipesannya.

\section{Mandiri}

Berdasarkan hasil penelitian Nilainilai pendidikan mandiri dalam novel Daun yang Jatuh Tak Pernah Membenci Angin karya Tere Liye ditemukan sebanyak 4 kutipan. Nilai pendidikan karakter dalam bentuk mandiri yaitu sikap dan perilaku yang tidak mudah tergantung pada orang lain dalam menyelesaikan tugas-tugas. Nilai-nilai pendidikan mandiri dalam novel Daun yang Jatuh Tak Pernah Membenci Angin karya Tere Liye ditemukan terlihat pada kutipan berikut:

"Dia tidak memaksa kami berhenti mengamen, meskipun aku tahu uang yang diberikanya kepada lbu jauh lebih banyak daripada semua penghasilan kami selama sebulan digabung. Biar lah, asal tidak mengganggu sekolah! Die tersenyum kepada Ibu saat mengatakan itu" (Tere Liye, 2016:34).

Konteks

Walaupun Tania sudah mendapatkan bantuan dari Danar, tetapi Tania tetap mengamen.

6. Rasa Ingin Tahu

Rasa ingin tahu yaitu sikap dan tindakan yang selalu berupaya untuk mengetahui lebih mendalam dan meluas dari sesuatu yang dipelajarinya, dilihat dan didengar. Nilai pendidikan karakter rasa ingin tahu digambarkan pengarang dalam novel Daun yang Jatuh Tak Pernah Membenci Angin karya Tere Liye ditemukan sebanyak 9 kutipan. Nilai pendidikan karakter rasa ingin tahu digambarkan pada beberapa tokoh seperti yang tergambar pada kutipan berikut:

a. Mengajukan Pertanyaan

Berdasarkan analisis data sikap mengajukan pertanyaan dalam novel 
Daun yang Jatuh Tak Pernah Membenci Angin karya Tere Liye tergambar pada kutipan nilai pendidikan rasa ingin tahu dalam bentuk mengajukan pertanyaan yang digambarkan oleh pengarang pada tokoh Tania.

"Komunikasi via satelit itu membantuku menjalani hari-hari sibukku. Aku bertanya banyak hal kepadanya. Dan dia menjadi lbu, teman, kakak, sekaligus ayah untukku" (Tere Liye, 2016:76).

Konteks

Walaupun jarak memisahkan Tania dan danar, mereka tetap salng berkomunikasi via satelit.

Dari kutipan di atas pengarang menggambarkan nilai pendidikan karakter rasa ingin tahu yang ditunjukan oleh tokoh Tania yang selalu penasaran dan bertanya pada Danar.

b. Menggali, Menjejaki Dan Menyelidiki

Berdasarkan analisis data sikap rasa ingin tahu menggali, menjejakidan menyelidiki dalam novel Daun yang Jatuh Tak Pernah Membenci Angin karya Tere Liye di gambarkan pengarang dengan menampilkan adanya rasa ingin tahu yang ditunjukan oleh tokoh Tania. Hal tersebut digambarkan pengarang ketika Tania bertanya masalah Danar yang menjauhi mereka. Kutipan tersebut menggambarkan salah satu deskripsi dari karakter rasa ingin tahu yaitu selalu bertanya.

"Sejak kapan kak Danar menjauh dari kita kalau terima telepon? Aku bertanya sambil menatap tajam Adikku" (Tere Liye, 2016:102).

Konteks

Tania makan siang bersama Danar dan Dede di Kantin mahasiswa sebelum berangkat ke bandara Canggi.

Berdasarkan kutipan di atas, pegarang menggambarkan karakter rasa ingin tahu pada Tokoh Tania. Rasa ingin tahu tersebut berbentuk menggali dan menjejaki perihal tokoh Danar yang selalu menjauh darinya ketika menerima telpon. Sehingga munculah rasa ingin tahu tokoh Tania.

\section{Bersahabat/komunikatif}

Berdasarkan hasil penelitian nilai pendidikan karakter bersahabat / komunikatif ditemukan dalam novel Daun yang Jatuh Tak Pernah Membenci Angin karya Tere Liye ditemukan sebanyak 8 kutipan. Berdasarkan hasil analisis indikator bersahabat yang digunakan pengarang adalah.

a. Senang Bergaul Dan Belajar Bersama Orang Lain

Berdasarkan analisis data sikap bersahabat atau komunikatif dengan indikator senang bergaul dan belajar dengan orang lain dalam novel Daun yang Jatuh Tak Pernah Membenci Angin karya Tere Liye di gambarkan pengarang pada tokoh Danar yang memiliki karakter bersahabat. Karakter tersebut tergambar ketika tokoh Danar yang mudah bergaul dengan orang yang baru dikenalnya. Karakter senang bergaul dengan orang lain tergambar pada kutipan berikut.

"Dia seperti biasa amat menyenagkan bagi orang yang baru mengenalnya. Bercanda. Bercerita banyak hal. Membuat ruang tamu itu terkadang diam mendengarkan. Melanjutkan berbinjangan lain, dan seterusnya" (Tere Liye, 2016:95).

Konteks

Pertemuan Tania dan Danar ketika di halte bus adalah awal kedekatan Danar dengar keluarga Tania.

\section{b. Memliki Kepedulian Dalam Berbagai Persoalan Dan Sosial}

Peduli adalah suatu tindakan yang didasari pada keprihatinan terhadap masalah orang lain. Peduli bisa pula 
merujuk pada sikap membantu, Berdasarkan analisis data sikap bersahabat atau komunikatif dengan indikator senang bergaul dan belajar dengan orang lain dalam novel Daun yang Jatuh Tak Pernah Membenci Angin karya Tere Liye di gambarkan pada kutipan berikut.

"Adi juga bersabar untuk idak terlalu jauh melangkah. Bersabar menunggu. Bersabar dengan semua proses. Kami hanya berteman dekat. Sejauh ini, cukup menyenangkan bagiku. Adi bisa menjadi sopir yang baik, dilevery man bisnis kueku, tukang fotocopi bahan kuliah, dan berbagai pernak-pernik lainnya" (Tere Liye, 2016:186).

Konteks

Tokoh Adi yang suka sama Tania smembuatnya melakukan apa saja untuk Tania.

Dari cuplikan di atas terlihat pengarang menggambarkan adanya nilai pendidikan karakter bersahabat / komunikatif yang ditunjukan oleh tokoh Adi terhadap tokoh Tania. Hal itu ditandai dengan tokoh Adi yang selalu berinteraksi dengan tokoh Tania dalam bentuk membantu Tania untuk keperluan-keperluan tertentu.

\section{Peduli Sosial}

Nilai pendidikan peduli sosial adalah sikap dan tindakan yang selalu ingin member bantuan pada orang lain dan masyarakat yang membutuhkan. Berdasarkan hasil penelitian nilai pendidikan peduli sosial dalam novel Daun yang Jatuh Tak Pernah Membenci Angin karya Tere Liye ditemukan sebanyak 13 kutipan yang menggambarkan karakter peduli sosial.
a. Menunjukan Keprihatinan Yang
Mendalam Kepada Orang Yang
Mengalami Penderitaan

Karakter peduli sosial bentuk menunjukan keprihatinan yang mendalam kepada orang yang mengalami penderitaan dalam novel Daun yang Jatuh Tak Pernah Membenci Angin karya Tere Liyedigambarkan pengarang pada tokoh Danar yang merasa prihatin dengan luka pada kaki tokoh Dede karena tidak memiliki sandal. Bentuk keprihatinan tokoh Danar tersebut digambarkan dengan memberikan uang sepuluh ribu rupiah kepada Tania untuk membelikan sendal Dede. Karakter tersebut tergambar digambarkan pengarang pada kutiapn berikut.

"Aku hanya menringis. Bagaimana kami bisa membeli sandal? Dia tersenyum menyeka ujung mataku. Saat kami akan turun, dia memberikan uang selembar uang sepuluh ribuan. Untuk membeli obat merah. Dede berseru riang menerimanya. Aku hanya mengangguk, menunduk, terima kasih! (Tere Liye, 2016: 24).

Konteks

Ketika turun bus Danar memberikan uang sepuluh ribu kepda Tania dan Dede untuk membeli obat merah.

Nilai pendidikan karakter peduli sosial yang ditunjukan dari kutipan di atas yaitu digambarkan pengarang pada tokoh Danar yang peduli dengan tokoh Tania pada saat Tania mengamen di sebuah bus kota. Sikap peduli Danar muncul karena Tania ketika mengamen tidak memakai sandal sehingga kakinya luka. Danar menunjukan sikap keprihatinan yang mendalam kepada orang yang mengalami penderitaan yaitu Tania.

b. Menunjukan Pengerbonan Kenyamanan Diri Demi Untuk Kebaikan Orang Lain 
Berdasarkan analisis data sikap peduli sosial dengan indikator menunjukan pengerbonan kenyamanan diri demi untuk kebaikan orang lain dalam novel Daun yang Jatuh Tak Pernah Membenci Angin karya Tere Liye di gambarkan pengarang pada tokoh Danar. Karakter tersebut ditunjukan oleh Danar ketika meluangkan waktunya untuk singgah dikontrakan yang disewakannya untuk Tania beserta ibu dan adiknya. Seminggu dua kali tokoh Danar mampir untuk membawakan makanan, buku pelajaran dan mainan untuk adik Tania. Tokoh Danar rela berkoraban agar keluarga Tania terbantu dari masalah kehidupan mereka. Bahkan Danar juga memodali meraka untuk membuka usaha jualan kue yang dia modali. Karakter tersebut tergambar pada kutipan berikut.

"Dia rajin seminggu dua kali singgah sebetar di kontrakan baru. Membawakan makanan, buku-buku untuku dan permainan buat adikku" (Tere Liye, 2016:35).

Konteks

Danar selalu menjenguk ibu Tania di rumah sakit,sebelum pulang kekontrakannya.

"Tentu saja semua modal usaha kue itu dari dia. Termasuk soal saran bentuk kue-kuenya. Dia sedikit pun tidak meminta bagian dari penjualan. Tidak sekali pun meminta Ibu untuk mengembalikanya" (Tere Liye, 2016:46).

Konteks

Tokoh danar memodali keluarga Tania untuk membuka usaha jualan kue.

c. Memberikan Kenyamanan Kepada Orang Yang Membutuhkannya

Di bawah ini kutipan yang menunjukan adanya nilai peduli sosial bentuk memberikan kenyamanan kepada orang yang membutuhkannya yang terdapat dalam novel Daun yang
Jatuh Tak Pernah Membenci Angin karya Tere Liye.

"Kak Ratna tidak marah, bahkan berkacakaca matanya. Dan dia membiarkan kami kali ini. Sekitar jam sembilanan, saat aku dan adikku jatuh tertidur di lorong itu, dengan ditutupi selimut yang di bawa Kak Ratna, aku mendengar keributan di sekitar kami" (Tere Liye, 2016:56).

Konteks

Ketika malam di rumah sakit, Ratna menyelimuti Tania dan danar yang tertidur.

Kutipan tersebut berisikan nilai pendidikan peduli sosial yang ditunjukan oleh Ratna. Bentuk peduli sosial tersebut berupa memberikan selimut pada Tania dan Dede yang tertidur di rumah sakit.

9. Tanggung Jawab

Berdasarkan hasil penelitian nilai pendidikan tanggung jawab ditemukan sebanyak 13 kutipan yang memuat nilai pendidikan karakter bertanggung jawab dalam novel Daun yang Jatuh Tak Pernah Membenci Angin karya Tere Liye.

a. Menyelesaikan Tugas Tanpa Diminta Atau Disuruh Untuk Mengerjakannya

Berdasarkan hasil penelitian nilai pendidikan tanggung jawab bentuk menyelesaikan tugas tanpa diminta atau disuruh untuk mengerjakannya dalam novel Daun yang Jatuh Tak Pernah Membenci Angin karya Tere Liye tergambar pada kutipan berikut.

"Sayang, waktu yang menyenagkan seperti itu selalu harus berakhir. Tepat pukul 22.00 dia dan Adikku harus kembali ke hotel. Aku dan Anne membereskan meja dan kursi yang berantakan, sebelum kembali ke kamar dorem kami" (Tere Liye, 2016:95).

Konteks

Saat acara ulang tahun Tania yang dirayakan di aula kampus, Tania dan Anne membersihkan kursi-kursi yang dipakai. 
Kutipan tersebut menunjukan adanya sikap tanggung jawab yang ditunjukan oleh tokoh Tania dan Anne. Mereka merapikan kembali meja dan kursi yang berantkan karena acara ulang tahun Tania. Hal itu merupakan tanggung jawab mereka selaku pembuat acara.

b. Memahami Dan Menerima Konsekuensi Dari Setiap Tindakan Yang Dilakukan

Berikut kutipan lain yang menunjukan adanya nilai pendidikan tanggung jawab bentuk memahami dan menerima konsekuensi dari setiap tindakan yang dilakukan yang terdapat dalam novel Daun yang Jatuh Tak Pernah Membenci Angin karya Tere Liye:

"Ibu memberikan pakaian terbaik yang disimpanya dalam buntalan plastic di atas para-para kardus. Baju terbaik? Baju itu sudah lusuh dan bau (baju itu terbaik karena tak pernah disentuh bertahun-tahun). Aku senang saja memakainya. Dede bahkan banyak menyimpul senyum" (Tere Liye, 2016: 17).

Konteks

Danar mengajak Tania dan Dede untuk membeli perlengkapan sekolah di toko buku.

Dari kutipan kedua terlihat adanya nilai pendidikan tanggung jawab yang ditunjukan oleh tokoh lbu. Tokoh Ibur merasa memiliki tanggung jawab untuk memberikanTania dan Dede baju baru. Baju yang sebenarnya lusuh dan bau, tetapi baju itulah yang istimewa karena tidak pernah dipakai dalam waktu yang lama.

Pambahasan

Pendidikan karakter adalah proses pemberian tuntunan pada anak untuk menjadi manusia seutuhnya yang berkarakter dalam dimensi hati, pikir, raga, serta rasa dan karsa. Sejalan dengan itu Wibowo (2012:36) menyatakan pendidikan karakter adalah pendidikan yang menanamkan dan mengembangkan karakter-karakter luhur kepada anak didik sehingga mereka memiliki karakter luhur menerapkan dan mempraktikannya dalam kehidupan baik dalam keluarga, masyarakat maupun bangsa.

Nilai-nilai pendidikan karakter menurut Wibowo (2012:43) adalah relegius, jujur, toleransi, disiplin, kerja sama, kreatif, mandiri, demokratis, rasa ingin tahu, semangat kebangsaan, cinta tanah air, menghargai prestasi, bersahabat, cinta damai, gemar membaca, pantang menyerah, peduli lingkungan, peduli sosial, dan tanggung jawab. Hal itu sejalan dengan hasil penelitian, nilai-nilai pendidikan karakter dalam novel Daun yang Jatuh Tak Pernah Membenci Angin karya Tere Liye yang digunakan pengarang meliputi religius, kerja keras, kreatif, menghargai prestasi, mandiri, rasa ingin tahu, bersahabat atau komunikatif, peduli sosial, dan tanggung jawab. Artinya nilai pendidikan karakter yang dikemukan oleh Wibowo berterima dengan nilai pendidikan karakter dalam novel Daun yang Jatuh Tak Pernah Membenci Angin karya Tere Liye.

Novel Daun yang Jatuh Tak Pernah Membenci Angin karya Tere Liye yang ingin disampaikan oleh pengarang agar seorang perempuan jangan mudah jatuh cinta dan tegar dalam menjalani hidup. Hal itu tergambar pada tokoh Tania memiliki karakter tegar ketika orang yang dicintainya menikah dengan orang lain, tetapi tokoh Tania tetap tegar dalam menjalani hidup ini. Selain itu, kehidupan ekonomi yang memprihatinkan dan ibunya yang sakit-sakitan tidak 
menjadi alasan buat Tania untuk kalah dalam menjalani hidupnya. Pada novel ini pengarang ingin menyampaikan rasa kesabaran seorang perempuan, dengan berbagai cobaan yang dialaminya. Tetapi Tania bertekad untuk menjadi perempuan yang lebih baik dan sukses mengejar cita-citanya.

Berdasarkan hasil penelitian, nilai-nilai pendidikan karakter dalam novel Daun yang Jatuh Tak Pernah Membenci Angin karya Tere Liye yang digunakan pengarang meliputi religius, kerja keras, kreatif, menghargai prestasi, mandiri,rasa ingin tahu, bersahabat atau komunikatif, peduli sosial, dan tanggung jawab. Nilai pendidikan karakter yang paling dominan dalam novel Daun yang Jatuh Tak Pernah Membenci Angin karya Tere Liye adalah kerja keras ditemukan sebanyak 17 kutipan, sedangkan nilai pendidikan karakter yang paling sedikit adalah mandiri ditemukan sebanyak 4 kutipan.

\section{SIMPULAN}

Berdasarkan hasil penelitian dan pembahasan, peneliti mengambil kesimpulan bahwa nilai-nilai pendidikan yang terdapat dalam novel Daun yang Jatuh Tak Pernah Membenci Angin Karya Tere Liye meliputi: 1) Nilai pendidikan Relegius seperti berdoa, berbakti pada kedua orang tua, berziarah kubur, bersyukur, dan iklhas, 2) Kerja Keras meliputi rajin dan dalam melakukan pekerjaan, enerjik dan penuh semangat dalam bekerja , 3) Kreatif meliputi memiliki kemampuan berpikir cerdas da cerdik, bernalar tentang sesuatu dari berbagai prespektif, melihat dari berbagai arah, 4) menghargai prestasi meliputi memberikan penghargaan terhadap prestasi yang dicapai orang lain, 5) Mandiri meliputi tidak bergantung pada orang lain, 6) Rasa Ingin Tahu meliputi mengajukan pertanyaan dan menggali, menjejaki dan menyelidiki, 7) Bersahabat/Komunikatif meliputi senang bergaul dengan orang lain, banyak beriteraksi dengan orang lain dan memiliki kepedulian dalam berbagai perseolan dan sosial, 8) Peduli Sosial meliputi menunjukan keprehatinan yang mendalam kepada orang yang mengalami penderitaan, menunjukan pengorbanan kenyamanan diri demi untuk kebaikan orang lain, memberikan kenyamanan kepada orang yang membutuhkannya dan 9) Tanggung Jawab.

Implikasi Novel Daun Yang Jatuh Tak Pernah Membenci Angin Karya Tere Liye dalam Pengajaran Bahasa dan Sastra Indonesia

Novel Daun Yang Jatuh Tak Pernah Membenci Angin karya Tere Liye dapat diimplikasikan sebagai bahan atau materi ajar dalam pengajaran Bahasa dan Sastra Indonesia di sekolah, bila dilihat dari tujuan pembelajaran sastra.

(1) Novel Daun Yang Jatuh Tak Pernah Membenci Angin karya Tere Liye banyak mengandung nilai pendidikan karakter sehingga membantu siswa dalam penanaman fondasi keluhuran budi pekerti serta pembentukan karakter yang jujur sejak dini, karena dalam novel tersebut para siswa akan mendapatkan bekal pengetahuan yang mendalam tentang manusia, hidup dan kehidupan, serta berbagai kompleksitas problematika dimensi hidup yang disebabkan oleh arus modernisasi. 
(2) Novel Daun Yang Jatuh Tak Pernah Membenci Angin karya Tere Liye dapat dianalisis secara intrinsik dan ekstrinsik. Salah satu unsur ekstrinsik karya sastra yaitu nilai pendidikan karakter. Melalui nilai pendidikan karakter yang terdapat dalam novel tersebut dapat melakukan pembinaan karakter dalam lingkungan sekolah melalui pengajaran sastra yang berdimensi karakter, moral dan akhlak.

(3) Novel Daun Yang Jatuh Tak Pernah Membenci Angin karya Tere Liye dapat dijadikan pijakan siswa dalam mengkaji kehidupan, karena di dalamnya terdapat nilai-nilai agama, sosial, moral, dan pendidikan karakter sehingga diharapkan dapat memotivasi siswa agar selalu ingat kepada Tuhan, memiliki kepedulian terhadap sesama makhluk ciptaan Tuhan, berperilaku baik, dan selalu rajin, disiplin, dan tekun dalam belajar.

(4) Setelah membaca novel Daun Yang Jatuh Tak Pernah Membenci Angin karya Tere Liye diharapkan dapat memotivasi siswa dalam meningkatkan penalaran dan imajinasinya sehingga menciptakan karya sastra yang baru.

\section{Daftar Pustaka}

Amin, Maswardi Muhammad. 2011. Pendidikan Karakter Anak Bangsa. Jakarta: Baduose Madia.

Aminuddin. 2011. Pengantar Apresiasi Karya Sastra. Bandung : Sinar Baru Algensindo.
Arifin,Bustanul, dkk. 2000. Analisis Wacana : Sebuah Kajian Bahasa dalam Pemakaian. Malang : Bayumedia Publishing.

Arikunto,Suharsimi. 2010. Penelitian Kualitatif.Jakarta: Bumi Aksara.

Aqib, Zainal dan Sujak. 2011. Panduan dan Aplikasi Pendidikan Karakter. Bandung; Yrama Media.

Azzet, Akhmad Muhaimin. 2011. Urgensi Pendidikan Karakter di Indonesia. Jakarta: Ar-Ruzz Media.

Hendrika, Maria. 2015. Universitas Bengkulu. Tesis Kajian Pendidikan Karakter Dalam Novel "Ayah Mengapa Aku Beda?" Karya Agnes Davonar (Pendekatan Strukturalisme)

Hidayatullah, Furqon. 2010. Pendidikan Karakter Membangun Peradaban Bangsa. Surakarta: Yuma Pustaka.

Khan, Yahya. 2010. Pendidikan Karakter Berbasis Potensi Diri. Semarang: Pelangi Plublishing.

Kosasih. 2012. Dasar-dasar Keterampilan Bersastra. Bandung: Yama Widya.

Muslich, Masnur. 2011. Pendidikan Karakter Menjawab Tantangan Krisis Multidimensional. Jakarta: Bumi Aksara.

Naim, Ngainun. 2012. Character Building. Jakarta: Ar-Ruzz Media.

Nurgiyantoro, Burhan. 2010. Teori Pengkajian Fiksi.Yogyakarta: Gadjah Mada University Press. 
Noor, Rohinam. M. 2011. Pendidikan Karakter Berbasis Sastra Solusi Pendidikan Moral yang Efektif. Jakarta: Ar-Ruz Media.

Ratna, Nyoman Kutha. 2012. Teori, Metode, dan Teknik Penelitian Sastra.Yogyakarta: Pustaka Pelajar.

Samani, Muchlas dan Hariyanto. 2012. Konsep dan Model Pendidikan Karakter. Bandung: Rosda Karya.

Semi, M. Atar. 1988. Anatomi Sastra. Padang: Angkasa Raya.

Sudaryat, Yayat. 2009. Makna Dalam Wacana, Bandung: Yrama Widya.

Siswanto, Wahyudi. 2013. Pengantar Teori Sastra. Yogyakarta: Aditya Media Publishing.

Sugiono, 2012. Metode Penelitian Kuantitatif, Kualitatif dan R \& D. Bandung : Alfabeta.

Sumardjo,Jakob dan Saini.K.M 2010. Apresiasi Kesusastraan. Jakarta:Gramedia Pustaka Utama.

Sukmadinata, Nana Syaodih. 2005. Metode Penelitian Pendidikan. Bandung: Remaja Rosdakarya.

Suyitno, 2014. Kajian Novel dalam Spektroskop Feminisme dan Nilai Pendidikan. Yogyakarta: Graha IImu.
Semi, M. Atar. 1988. Anatomi Sastra. Padang: Angkasa Raya.

Sudaryat, Yayat. 2009. Makna Dalam Wacana, Bandung: Yrama Widya.

Tere Liye. 2016. Daun Yang Jatuh Tak Pernah Membeci Angin. Jakarta: Gramedia Pustaka Utama.

Wardhana, Dian Eka Candra. 2006. Representasi Tindak Tutur Direktif Penutur Jawa Pendatang yang Diekspresikan secara Verbal dalam Komunikasi Lisan Tidak Resmi Masyarakat Multietnik di Bengkulu. Desertasi Pasca Sarjana Bahasa Indonesia Universitas Negeri Malang. Tidak Diterbitkan.

Wibowo, Agus. 2012. Pendidikan Karakter. Yogyakarta: Pustaka Pelajar.

Yaumi, Muhammad. 2014. Pendidikan Karakter Landasan, Pilar dan Iplementasi. Jakarta: Prenadamedia Group. 